\title{
Analysis of Participatory Processes in the Formulation of Spatial Plan for Nature Park Medvednica
}

Nataša Lovrić

Croatian Forest Research Institute Regional Office for South East Europe (EFISEE)

Vilka Novaka 50 c, 42000 Varaždin, Croatia natasal@sumins.hr
Marko Lovrić

Croatian Forest Research Institute Regional Office for South East Europe (EFISEE) Vilka Novaka 50 c, 42000 Varaždin, Croatia

\section{Ivan Martinić}

Faculty of Forestry, University of Zagreb Svetošimunska 25, 10000 Zagreb, Croatia

\section{Abstract}

Background and purpose: This research aims to assess the stakeholders influence on spatial planning of Nature Park Medvednica, a mountainous protected area adjacent to Zagreb, the capital city of Croatia, which tries to hold on to the pressure of the urbanization. Because of the inexistence of spatial plan which is required with the Croatian laws, its area was significantly decreased in 2009. This kind of research has not been done yet for NP Medvednica, and it will provide a contribution to the process of developing a spatial Plan for NP Medvednica.

Materials and methods: The study was conducted in the framework of stakeholder analysis, for which a series of indepth interviews with - stakeholders were performed, and documents concerning the spatial plan were analysed. The data gained was processed in MAXQDA software for qualitative analysis.

Results and conclusions: The gathered data explains which are the disadvantages of the tree processes of the formulation of the spatial plan and is giving a possible theoretical explanation or a model which can be implied in any decision making process involving stakeholders in natural resources management in within a given political and cultural context. Description of the past and current spatial planning situation of the NP Medvednica was specified and issues and stakeholders concerning the creation of the spatial plan where identified. The key conflict areas that affect the formulation of spatial plan were detected and examined. The level of participation of stakeholders in the context of fulfilment of their own interests was assessed as well as the influence on participation processes of different stakeholder groups on the formulation of the spatial plan. In order to have proper citizens and stakeholders participation some changes in the legislation should take place.

Keywords: stakeholders, participation, spatial planning, protected areas

\section{INTRODUCTION}

Protected Areas (PAs) are some of the most important refuggium of biodiversity on earth and recent literature has emphasized their importance [1]. Their stakeholders often have divergent demands like biodiversity conservation and local livelihoods, and aspire for the PA ecosystem to be utilized/ exploited/ protected according to their priorities. PAs do not exist in sociopolitical vacuum, and are prone to negative feedbacks from these societal implications. If only for the sake of conservation, it is important to reduce conflicts in conservation and to incorporate local perspectives in PA policies. However, recent literature does not offer clear consensus on the most suitable approaches for inclusion of local communities in decision making. A good tool for the above mentioned is Stakeholder Analysis (SA), a technique developed in management studies $[2,3]$. SA is variously used as an approach or tool for generating knowledge about actors (individuals or organizations), to understand their behaviours and interests, and for assessing their value to decision-making [4]. Stakeholder Analysis is a critical tool in clarifying the micro political economy of a policy area and can help identify interested parties that should be incorporated in the decision-making process, in addition to understanding the basis for their inclusion. Three key benefits to undertaking stakeholder analysis we can identify. By using a stakeholder analysis, one can facilitate inclusion of stakeholders that otherwise would be overlooked or marginalized. There is a descriptive and normative approach to the process that reveals power relationships that ensure values. The process can be a contribution to democracy with improvement of the decision making as well as bringing legitimacy to the process by incorporating a wide range of stakeholders' knowledge. It also helps to identify current/ future opportunities and threats in projects to improve policy 
design and implementation [5]. SA helps to find compatibility between policy objectives and stakeholder aspirations, and helps managers to choose between short-term and long-term policy objectives, or balance conflicting objectives such as conservation, development, equity and peace $[6,7]$. These aspects make SA particularly relevant to Natural Resource Management (NRM) [8]. Though a PA may accrue a net gain for society, the benefits could go to a party that is not disadvantaged and compromises an already marginalized group [9]. These marginalized populations often depend on the natural resources, and it may be unadvisable to ignore their needs [8]. Hence, the need for dynamic stakeholders' interactions and partnerships for conservation has been stressed across recent literature [10]. SA can help to foresee socio-political obstacles to PAs and identify alliances, both existing and potential. Stakeholder analysis can be a powerful tool for nature protection researchers because the method allows a visible representation of both variations of power, as well as the different spatial scales in which the stakeholders operate [11]. Mushove and Vogel [12] used stakeholder analysis for forest reserve conservation management in Mozambique to better understand land-use disputes. Stakeholder identification and management (without categorization) uses methodologies that are robust and can be effective in environment that supports performance management and planning $[13,14]$. Savage [15] and Mitchell [16] gave interesting definition of categories of stakeholders. According to them there are four generic types: supportive, mixed blessing, no-supportive, marginal. They develop an eight part stakeholder typology based on assessment of the strength of three attributes: power, legitimacy and urgency.

Comprehensive stakeholder identification, assessment and engagement that can be met in Cleland [17], who identifies stakeholders and their interests, measures these interests, and attempts to predict their future behaviour and its impact on the project and on the project team. In contrast to this Briner [18] focuses on communication as important part of stakeholder management. Fletcher et al. [19] describes stakeholder identification as a process for mapping stakeholders expectations based on value hierarchies and key performance areas (KPA). Frooman [20] gives an analysis of ways through which organizations can plan their stakeholder's management strategies, rather than only response strategies. Turner and Veil [21] use more holistic approach to stakeholder identification, which encompasses assessment of awareness, support and influence, all of which culminates in development of a stakeholder knowledge base. Lopez et al. [22] give a very detail analysis of stakeholders; the research goal was to describe how the functioning of the Park distributes its benefits and costs among local population, and to formulate strategies for the enrolment of stakeholders in decision making processes, by which the conservation goals could be reached. The focus of the research was on the issues of deforestation and commercial illegal logging. The high level of analysis was reached through usage of triangulation, which comprised of in-depth interviews (15\% of local population), three different contingent valuation applications (targeted at visitor groups), a forest inventory study, and a cost-benefit analysis of management scenarios. Similar level of analysis was reached by Cho [23], who developed an interpretative planning model for a national park system of Korea. His triangulation consisted of in-depth interviews (use of SWAN framework - Stakeholder Wants and Needs Analysis) in combination with Resource Protection Criteria (RPC) and Park Management Criteria (PMC). Prell et al. [24] made a case study on Peak district National Park, in which they focused on the relations among stakeholders through application of stakeholder network analysis (more than 200 stakeholder groups identified). In the contrast to a situation with many stakeholder groups Suman et al. [25] did a case study on The Florida Keys National Marine Sanctuary, in which they had focused on in-depth scenario-analysis of participation of three key stakeholder groups. The following step in stakeholder analysis was done by Jennings et al. [26], who on a case study of the Lower Fitzroy and Port Curtis catchments where used the SA as a tool for capacity building. After performing face-to-face interviews and secondary research, the researches created "social maps" of all stakeholder groups, which were later used to build capacity of stakeholders for enrolment in decision making processes by a series of structured negotiation sessions. A similar conclusion was given by Christie [27], who (without the usage of SA) did a comparative study of four Marine Protected Areas in SE - Asia, and found that just by looking at biological elements of protected area without recognition of social demands of stakeholder groups - especially local people, the protected area management regime was in fact a failure. To this end the work of Renard et al. [28], which gives an overview of 6 SA applications in PA of the Caribbean region, states that for effective enrolment of stakeholders in decision making capacity building and project manager communication skills are essential. Stakeholder analysis is also a building block of the ecosystem approach of IUCN to management of natural resources on local level [29]. With this in mind, Brenner [30] performed a stakeholder analysis in a case study of the Great Smoky Mountains National Park. This research identified 29 stakeholder groups and focused on issue priorities and stakeholder power. The importance of SA in spatial planning was stressed by Enserink [31], who in his paper pointed out the necessity of usage of SA in the early stages of big infrastructure investments in Netherlands, where traditional reliance on secondary data about stakeholders has led to many public negative actions to big investments. He proposes a "Stakeholder quick scan", which is a combination of key informant interviews and focus groups.

\section{Study Area - Nature Park "Medvednica"}

Medvednica is a mountain north of Zagreb, on most of which surface the Nature Park Medvednica is lo- 
cated. The area of the NP today is 17,938 ha and the highest peak is Sljeme (1033 m). Medvednica is $42 \mathrm{~km}$ long and extends from the east-west direction (namely, northeast - southwest); the surface of the mountain is mostly forested. In mid-1981 western part of mountain Medvednica, with area of 22826 ha and between the Podsused and Kašine, was declared a nature park [32]. The natural phenomenon upon which the Park was established were well preserved natural forest phytocenoses, which span on about $65 \%$ of the area (By decree in 1998). Later on the Government of Croatia had founded the Public agency "Park Prirode Medvednica", which is responsible for the management of the park. Today the agency employs 17 people.

Adoption of the Act was preceded by an expert research and elaboration of State Institute for Nature Protection. According to the Law on Nature Protection [33], the nature park category includes the vast natural or part of the cultivated area with a distinct aesthetic, ecological, educational, cultural tourist and recreational values. Nature Protection Act states that the protection, regulation, promotion and use of National Park and Nature Park should be determined by a spatial plan, and that the plan should be approved by the Parliament of Croatia. In order to systematically protect natural values, especially the most important spatial objects of protection, a Spatial Planning Program of Croatia [34] was developed, which provides guidelines and orientation for making spatial planning laws for declared natural parks, including Medvednica. According to Law on Spatial Planning and Construction [35] the spatial plan for area of special characteristics has to be made for nature parks, and represents the fundamental management document, with which all other document have to be aligned with. The responsibility for the spatial plan of nature park Medvednica is with the Ministry of Environment, Spatial Planning and Construction, and the obligation for its creation lies at the Municipal Bureau of Planning of the city of Zagreb.

In 1989 the first draft spatial plan was prepared and sent to a public hearing with a Decision about making Spatial plan for areas of special-purpose Nature Park Medvednica [34] The plan developed by the Urban Institute of City of Zagreb in 1989 was not adopted. In 2005 the Department for Planning of City of Zagreb prepared and proposed a plan for renewed public debate. The holder of the plan was the Ministry of Environment and Physical Planning. Starting points for the draft of the spatial plan of Nature Park Medvednica (2005) were the Spatial Planning Strategy and Program of Spatial Planning of Croatia, the applicable regional plans and county-level cities and municipalities, and the general master plans and regional plans. Studies, surveys and elaborates were made for the Nature Park Medvednica regarding the creation of the spatial plan; although numerous, the largest part of them was obsolete. The Public Hearing pointed out some problems: the boundaries of the protected areas, the treatment of the particularly valuable areas in the nature park, traffic connections with Region Zagorje
By building a Tunnel under Medvednica which needs to be connected to Zagreb area with so-called "Northern Tangents" ((Studies 2006 and 2009) Transportation and utility infrastructure) as well as with and the problem of locating the new cable car station at the top of the mountain. Tunnel through Medvednica was scheduled to be built as part of the Northern bypass of Zagreb that is provided in a length of 25 kilometres, and it should connect the highway to Varaždin and highways for the Krapina. City of Zagreb has signed a contract with the Faculty of Civil Engineering and ordered studies for the building of the northern bypass around Zagreb, which is related to the construction of the tunnel through Medvednica. This plan until now was not accepted and it is not being incorporated as such in the third draft of the plan. Environmental Committee of the Croatian Parliament at its eleventh session held on September 16th 2009 made a statement in which they changed the boundaries and reduced the area of the park to a smaller surface of 17,938 ha, the parliament voted positively and changed the boundaries. This was never presented to the public or putted on a public debate. This statement is based on "The specialized background to change the boundaries of the park Medvednica" made by the State Office for the Protection of Nature in July 2005. The proposal of the Ministry of Environment, Spatial Planning and Construction was to completely distinguish (without overlapping) Medvednica Park Spatial Plan from the City of Zagreb, which has been accepted and included in the statement. With the Law on Amendments to the Act to designate the western part of the Nature Park Medvednica [32] the new borders of the park with total area of 17938 ha where established in 2009.

Afterwards boundary modifications, changes to regulations in the field of nature and environment protection were made. The results of environmental impact assessment study and reconstruction of the lifts to Sljeme where consequences of the public discussion, but were not accepted. Forest management in NP Medvednica is mostly in the hands of the state forests management company "Hrvatske Šume" Ltd. ("Croatian Forests"), while their activities are supervised by "Park prirode Medvednica" public institution. However, problems in the vast majority of cases occur in private forests, which are sometimes managed by their owners irrespectively of the legal obligations of private forest management, and there instances of illegal conversion of forest land into construction plots.

Pollution and wild litter depots are constant problems that occur within the park and as a consequence, these influences of the environment to the people who live near the park are present and constant. At the moment, there are four quarries in Medvednica. Currently active quarries are called Bizek and Jelene Vode. Remediation is being practiced and it is not allowed to further expand the existing or to create new quarries. The biggest problem with the quarry is currently the illegal exploitation of green slate and the creation of landfill waste in quarries that are not being repaired. 


\section{MATERIALS AND METODS}

This research analyse the stakeholders and their participation and influence in the processes of the formulation of Nature Park Medvednica's spatial plan by using stakeholder analysis for their identification. The official stakeholders list for creation of the spatial plan was used as a starters point. All that was be undertaken to interpret the data through the framework of stakeholders analysis their mapping and the level of their participation. This is an applied research, which is descriptive - explanatory, has cross-sectional direction and Inductive approach. Unit of analysis are interest groups, or formal and informal groups, and unit of data gathering are individual stakeholders of the Medvednica's spatial planning process. The data used for this research are past and present documents and acts as well as meetings recordings analyses, reports and articles. The information that are gathered is data on spatial characteristics of Nature Park Medvednica; Spatial planning drafts and all background studies and maps; data on policy development of spatial planning in Nature Park Medvednica; A review of policies and site specific documents. The general data gathered is the review of the relevant literature, reports and of historical data.

\section{Qualitative data}

This part of the research is based on semi-structured in-depth interviews with stakeholders and their representatives as well as with identified key informants. The identified stakeholders list was used for assessing the stakeholder's participation trough the ladder of participation [36]. As a starter point for stakeholders' identification an official stakeholders list of the creators of the plan was used. The further identification of stakeholders was done by impact zoning [37], following the guidelines of Brown [38]. The additional development of stakeholder list was done via snowball technique and key informant in order to identify the excluded stakeholders. The analysis was performed through MAXQDA software package for qualitative research. In this study a Stakeholder's analysis was made in order to be able to assess their participation and in the same time identification of their interest areas was done to see if there is some overlapping. Every interviewed stakeholder had a chance to draw on a map its area of interest. The stakeholders and their interest areas identification trough spatial and physical mapping on Medvednica were compared to the once that are being taken in consideration for the analysis of the last version of the spatial plan, and changes of the borders.

\section{Theoretical framework}

The process of creation of a spatial plan in Croatia necessitates participation approach; however, the term participation can encompass anything ranging from a merely discarded obligation in the context of informing the public up to binding agreement on implementation. For this reason it is very important to analyse the level of participation of different stakeholders on the one side, and their motivations for the enrolment in the participation process on another.

The level of stakeholder's participation was assessed through the framework of "ladder of participation" [36], in which the author describes the level of participation in the decision making process through eight steps: Manipulation, Therapy, Informing, Consultation, Placation, Partnership, Delegated power and Citizen Control (Figure 1). The assessment is done in order to see the amount of citizen's power in determining the final decision. "Manipulation" and "Therapy" describe the levels of "non-participation" that are being used by some processes to substitute the genuine participation. With that people are participating like in this case trough public display only to be able to let the power holders to "educate" or "cure" them (Figure 4). "Informing" and "consultation" are used by the power holders to hear the citizens, but in reality their views won't be taken into consideration. If participation is limited only to these levels you cannot have a final product and does not give a chance for changing the status quo. We have taken into consideration classic model of public participation and deliberative democracy with Sherry Arnstein's ladder of public participation as well as taking into accounts a more recent scholarly framework by IAPP (IAP2) [39] public participation spectrum of public impact. As you move from left to right on this spectrum, the level of citizen involvement and impact increases. On the left, there is no or little citizen involvement and impact, and on the far right, citizens have complete control of the public participation process and outcomes (Figure 2). We can only asses these results through Arnstein's ladder because obviously these systems that we research can be described as deliberative democracy. The newest IAP2 spectrum for accessing the level of participation cannot be implied because it takes into consideration only the decision making processes that have public impact and influences at the direct decision making process. Even if we would do the assessment, we cannot go further than the first rug, and that is discountable. The first rug "Inform" is described as public providence with balance and objective information. With informing them in the same time you assist them in understanding problems, giving them alternatives and opportunities, or sometimes even solution. With the presented results from the research so far we cannot find evidence that proves any of those, besides just pure informing. Looking at the first ladder of participation and the latest one used in democratic systems compared to the others used before, we can conclude that the first one is more applicable to the current situation and to the process made in 2005. That can be described as lack of democracy, or is that going backwards? Some can say that we are reinventing the things that already existed in the past political structures. The respective level of participation is a reflection of stakeholders interest to participate, and also partly of its power. In order to assess the power relations of stakeholders in more detail, the "Power Tools" [40] of the International Institute for 
Environment and Development are going to be used. These documents represent the conceptual framework and methodology guideline for the stakeholder analysis's section on power distribution and relations.

This research will try to find out whether stakeholders perceive the process of spatial plan formulation as a process which favours all of its participants in an equally favourable way. And did they manage thorough power and informal participation to accomplish their interests on Medvednica. Stakeholder's power can also be proved trough mapping their interest zones (Figure 3). Until now the results showed a succeeded reduction of those areas in order to accomplish their interest trough informal participation. With not implementing a proper participation people leave space for informal ways of participating and having a good political back up for it through their lobbying groups. Making a ski resort and many different touristic attraction places in the top of the mountain, where is the I zone of most strict protection and where no works and changes of the nature are allowed, as well as reducing a protected areas is one of the best ways to prove that.

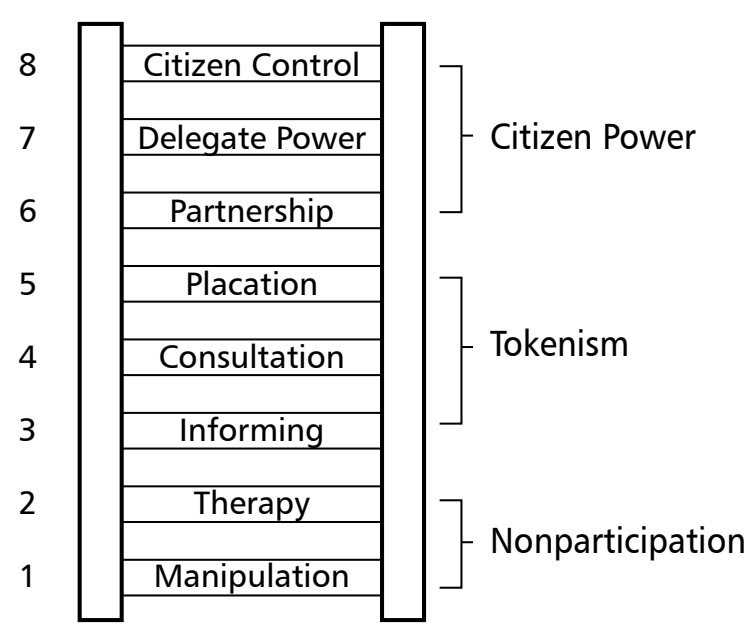

FIGURE 1

Sherry Arnstein [36] - Public Participation as 8 rungs on a ladder

\section{Public Participation}

Level of Citizen Involvement and Impact

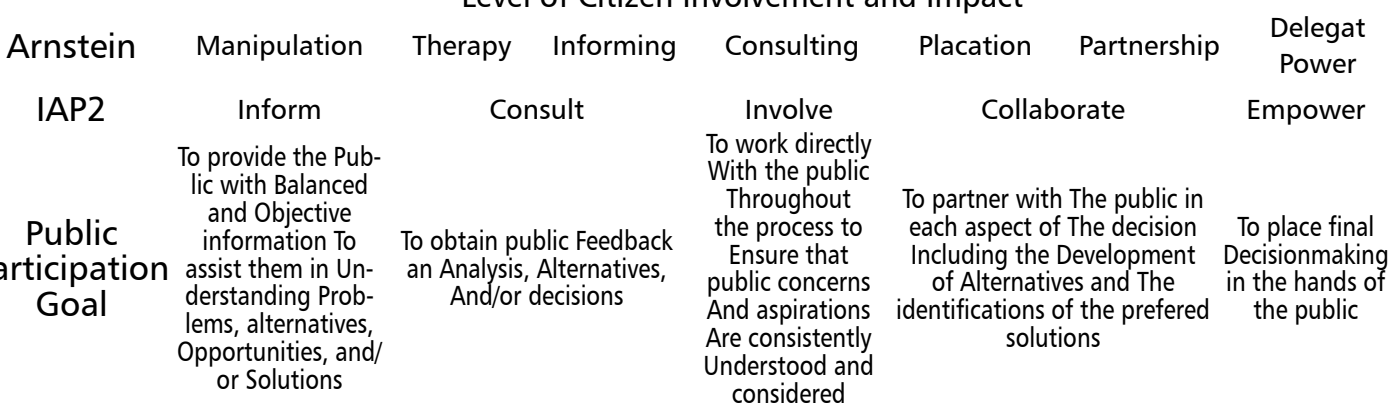

Spectrum adapted from International Assotiation of Public Participation (IAP2) parctitioner tools

FIGURE 2

Spectrum of public participation

- Sherry Arnstein [36] - Public Participation as 8 rungs on a ladder

- IAP2 [39] - Public participation spectrum

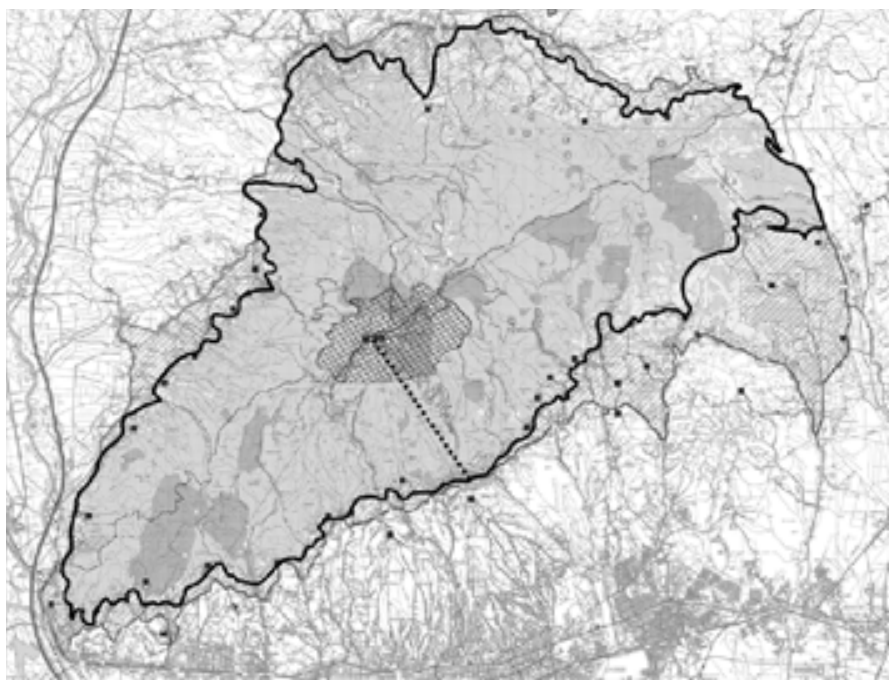

\section{LEGEND}

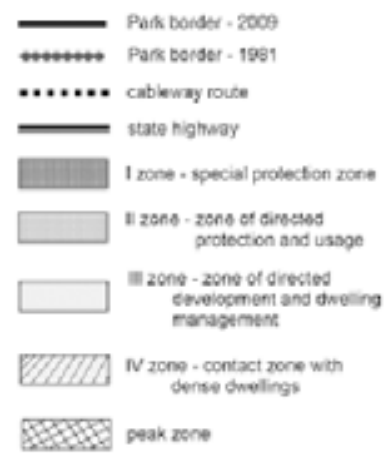

FIGURE 3

Old and new Borders of NP Medvednica overlapping with stakeholder's interest areas and stakeholders power mapping. 


\section{RESULTS}

Nature Park Medvednica is trying to bring a spatial plan for more than 30 years. Historically and politically speaking they can be divided in 3 periods (Figure 4, $5,7)$.

In the First period 1981-1991 during Former Republic of Yugoslavia the contractor of the plan was the City of Zagreb with the city committee for Spatial Planning, and communal matters. The implementing agency was the City of Zagreb's Urbanism bureau. 19 people were involved in designing of the plan, and they had consultation of 26 experts in different fields. 9 studies were conducted only for the purpose of that plan. Stakeholders meeting, pre meetings and consultations where made with 44 identified stakeholders. For citizen consultations a survey was made with the residents of Medvednica, and they were also consulted trough the public forum. Although many of the respondents were critical of the Former Yugoslavian Regime, this first attempt to bring the spatial plan had the longest list of participating stakeholders, the participation itself was most substantive, almost all stakeholders were taken into consideration, as their list was as almost as big as the list prepared within this research. Many stakeholders consultations and meetings where done in that time. The meetings where constituted of all stakeholders sitting at the same table and bringing decisions into place. The Former Yugoslav time maybe was considered as non-participatory but this study showed that was the most participatory of all the tree time periods researched, including post war transition period as well as the pre EU accession period.

Second Period 2002-2008 Post War and Transition period; the coordinator was Ministry for Environmental protection, spatial planning and construction and the minister itself was the main leader. The conductor was City of Zagreb, Bureau for spatial planning. They have consulted and recognised 21 stakeholders and 23 people were part of the executive crew that made the plan. They only consulted 5 experts and 8 studies were made in that purpose. Public forum consisted out of public presentations and discussion of the implementing agency of the plan and the stakeholders, who came on voluntarily basis, were present there as well. After that there was a 30 day notice in which unsatisfied stakeholders can submit a complaint, which might or might not be accepted. The notice about the public forum was sent to all the media and everyone who felt like they were affected by the plan could come and be part of the forum. The Spatial plan was presented for the public on 28th of September 2005. A public forum initiated discussions of the spatial plan of the NP Medvednica. The panel was constituted from a considerable number of stakeholders; including members of different sections of public administration, concerned citizens, various environmental NGOs and residents of mountaineers and municipalities directly affected by the changes in the new spatial plan. The discussion had very turbulent flow in which people sought chang- es in the plan and had a very aggressive stand towards the presented situation and respective state's agencies. Many of them had felt that they were deprived of their wealth, because due to prior media information, their real estate within the borders of Nature Park was expected to have drastic fall in prices. There has been great interest in the new regulation, which was directly related to the Sljeme ski resort (Ski resort is managed by the city company "Sljeme - Medvednica"). With the plan Medvednica should be divided into four zones. Construction is allowed in the fourth zone, which is the marginal zone of the park, where there are already buildings; the first zone marks the upper part of $\mathrm{Na}$ ture Park; where any construction is prohibited, and were strict regulations of nature preservation apply. The ski resort mostly falls into the first zone but no significant changes were made for it, was the official explanation, except that is being actually built in the first zone; the whole complex of ski resorts (in today's state) entered the draft of the spatial plan. The regional plan also included a new cable car that goes on the north side of Medvednica, and against which there were passionate comments expressed by the environmental NGOs representatives. Also, the spatial plan is regulating and reducing the traffic on the top part of Medvednica and brings regulation (prohibition) for any kind of construction in the first zone. Ministry of Culture which is responsible for the nature protection and the Ministry of Environmental Protection, Physical Planning and Construction, which is the holder of the Spatial Plan process, has initiated the adoption of the amendment for changing the nature park boundaries, followed by a spatial plan proposal within the scope of the new boundaries. State Bureau for Nature Protection has received the task to create the technical base for the adopted Law on amendments to change Medvednica Nature Park borders, the proposed expansion of the park on the eastern slopes of Medvednica. The professional background proposed reduction of 3365 ha and an increase of 5712 ha and with that the total area supposed to be 25173 ha. That proposal for increasing the borders was rejected and on 13.02.2009 was finally adopted by the Parliament with the changes of the Law Amendment for western part of Medvednica designation [41]. This time the proposal was accepted with decreased area by 4888 ha. The final proposal of the area of Medvednica with 22826 ha was replaced by 17938 ha.

In the third Period 2009-2012 the Pre EU accession period the one who ordered and coordinated the spatial plan was Ministry for Environmental protection, spatial planning and construction and the minister itself was the main leader. The conductor was City of Zagreb, Bureau for spatial planning. In this period 26 stakeholders are officially part of the stakeholders list. From them only 9 are being consulted at the "pre meeting", but not all of them at the same time and on the same table. The rest of them (17 stakeholders) were not being consulted but they will be invited to the public forum. The public forum still has not taken place and the plan is still in procedure. 


\section{Period assesment on Arnsteins' Ladder}

$$
7
$$

5

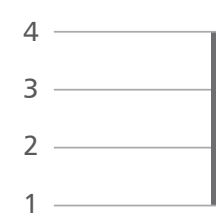$$
1
$$

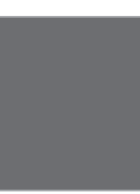

I Period
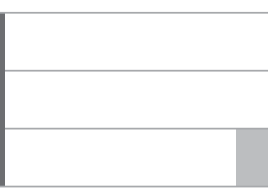

II Period

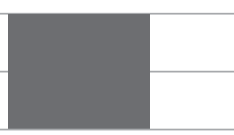

III Period
8. Citizen Control

7. Deligated Power

6. Partnership

5. Placation

4. Consultation

3. Informing

2. Thewrapy

1. Manipulation

\section{FIGURE 4}

Period's assessment on [36] ladder

We can clearly see that in the first period they have gone the most high on the rug of the ladder of participation with Consulting, in the second period we can say that they have come as far as the Therapy rug, but in the third period there is a slight improvement as far as the informing rug comes.

In this tree period comparison we can see that numbers of stakeholders were much bigger in Former Yugoslav times with 44 of them, in the second period there were 21 , and in the third period slightly more

with 26 . The same goes with the experts involved, they were 26 in the first period, 5 in the second and 17 in the third. Nine studies were made in the first period, 8 in the second and only 2 in the third. The only thing that is clear is the smallest number of people involved in the creation in the first period. If we see that in the third period there is the biggest number of people involved in the creation, we can conclude that is not the clearest formula for good achievements, as there should have been an increase in the studies made and stakeholders and experts involved.

\begin{tabular}{|c|c|c|c|c|}
\hline \multirow{2}{*}{$\begin{array}{l}\text { III Period;Nr. } \\
\text { Stakeholders; } \\
26\end{array}$} & \multicolumn{3}{|c|}{3 Period Comparison } & \multirow[b]{3}{*}{$\begin{array}{c}\text { III Period; } \\
\text { People } \\
\text { involved in creation } \\
30\end{array}$} \\
\hline & I Period & II Period & III Period & \\
\hline $\begin{array}{c}\text { II Period;Nr. } \\
\text { Stakeholders; } \\
21\end{array}$ & & & & \\
\hline \multirow{5}{*}{$\begin{array}{c}\text { I Period;Nr. } \\
\text { Stakeholders; } \\
44\end{array}$} & \multicolumn{2}{|c|}{$\begin{array}{l}\text { III Period; Experts } \\
\text { involved; } 17\end{array}$} & & \multirow{2}{*}{$\begin{array}{c}\text { II Period; } \\
\text { People } \\
\text { involved in creation; } \\
23\end{array}$} \\
\hline & \multicolumn{2}{|c|}{$\begin{array}{l}\text { II Period; Experts } \\
\text { involved; } 5\end{array}$} & & \\
\hline & \multirow{3}{*}{$\begin{array}{c}\text { I Period; } \\
\text { Experts } \\
\text { involved;26 }\end{array}$} & & $\begin{array}{l}\text { III Period; Studies } \\
\text { Made;2 }\end{array}$ & \multirow{3}{*}{$\begin{array}{c}\text { III Period; } \\
\text { People } \\
\text { involved in creation } \\
19\end{array}$} \\
\hline & & & $\begin{array}{l}\text { II Period; Studies } \\
\text { Made;8 }\end{array}$ & \\
\hline & & & $\begin{array}{c}\text { I Period; } \\
\text { Studies Made;9 }\end{array}$ & \\
\hline
\end{tabular}




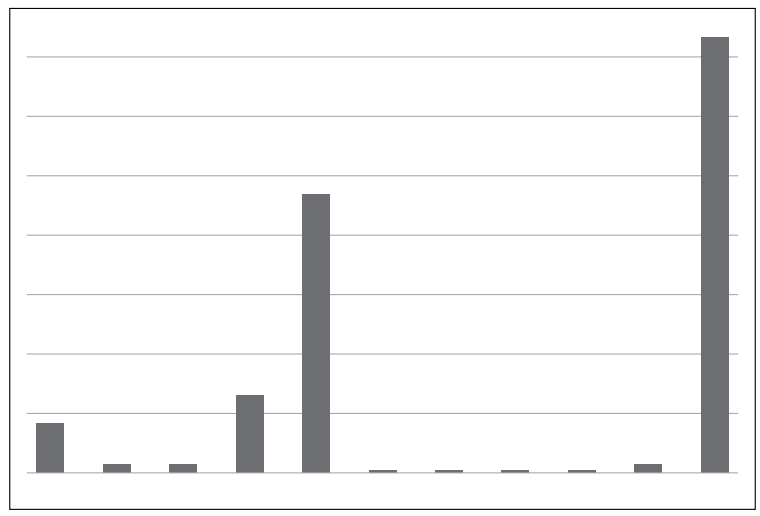

\section{FIGURE 6}

Number of complaints made by citizens on the public forum in 2005

In 2005, 733 complain were submitted by stakeholders, of those only 81 "accepted" and 473 are being "rejected" (Figure 6). 12 were "Partially accepted" and 14 were "already incorporated in the plan". On 131 of the complaints were answered with "it is not part of the plan". The answer "It is repeating itself" got 1 complaint, "no replay" got 2 complaints and "it is about changes of the border not about the spatial plan" got 1 complain. There were even 3 answers "it is not a complaint" and 15 of them were replied with "it is not being revived". If some citizens' complaints were anonymous or the address is not correctly written or is unknown, the complaint was automatically rejected. All of the rejected complaints got the same generic answer, without substantive explanation why their specific request wasn't accepted.

In Figure 7, it can be seen that only in the first period most of the indicators for participation were followed true with experts meetings, public forum, stakeholder's meetings and survey, and in the second and the third period just half of them where completed; the experts meetings (pre-meetings and public forum).

\section{DISSCUSION AND CONCLUSIONS}

Nature Park Medvednica is trying to bring a spatial plan for more than 30 years. Historically and politically speaking they can be divided in 3 periods. NP Medvednica was Founded 1981 and in 2012 there is still an on-going third process of creation of the spatial plan (This research is being made in the period of 20102012 and it is still on-going as part of a PhD thesis). For all three processes it can be said that there is the same outcome no matter what the political state is, no spatial plan came out of them. What can that be dependent of? Is it the cultural background, the specific norms and values or something else? The bureaucracy leading the process indifferently, without a motive to enhance their efforts as well as the interested sides influencing the decision making in order to be able to accomplish their goals? There is not presence of consultations with public participants in any kind, besides the public forums. In which category we can place the public forums and occasional consultation with few of the stakeholders which are not even a real stakeholders according the definition's but part of the Spatial Plan constructors by default taken into account since they are parts of the state administration. In order to have citizens and stakeholders participation some changes should be made in the following legislations:

- The provisions of Article 137 Paragraph 2 and Article 142 paragraphs 3 and 4, Environmental Protection Act ("Official Gazette", No. $110 / 2007$ Regulation on public participation and public concerned in environmental matters ("Official Gazette" No. 64/08);

- Article 29a. Paragraph 2. Law on Spatial Planning ("Official Gazette" no. 30/94 and 68/98), Regulation on public consultation within the making of spatial plans (NN 101/98).

\section{| Period II Period III Period}

\begin{tabular}{c|ccc} 
Yes & Yes & No & No \\
\hline Yes & Yes & No & No \\
\hline Yes & Yes & Yes & Yes \\
\hline $\begin{array}{c}\text { Experts } \\
\text { meetings }\end{array}$ & $\begin{array}{c}\text { Public } \\
\text { forum }\end{array}$ & $\begin{array}{c}\text { Stakeholders } \\
\text { meetings }\end{array}$
\end{tabular}


The model that comes in the final phase of this research will bring some directions that can help in making the changes of that legislation. If the new models would be directly implied we will see whether some of the stakeholders opinions where true. There is always a possibility that if you apply a proper participation than you can see the right results from it. Almost all respondents working in public administration refer that they respect the guidelines from those regulations. Obviously they do not reach satisfactory levels of participation. Citizen's involvement should be made in the whole process from the beginning of the making of the plan by educating them and making focus groups in taking on their opinion of the suggestions and educating them in order to avoid their personal gains involvement in the spatial planning. With making the process more transparent and participatory you leave small space for political and personal accomplishment, lobbying of separate stakeholders and informal participation. The research showed that all the tolls already existing in Europe or wider are not necessary applicable in this different cultural and political environments in which other norms and ethical values apply. Many of the members of the implementing agency think that public forum is more than enough for stakeholders and citizens participation, since it is not in the culture of people to participate at such events; so within this setting, there is no need for enhanced participation. Representatives of stake-holding groups think that is necessary to make the changes and involve the stakeholders and citizens in a "proper way" in decision making, and there are the comments on the bureaucratic structure that they are not motivated enough to practice proper participations with the same financial support they receive. Croatia is one of the countries who signed the Aarhus Convention [42]. Three articles of the Aarhus Convention are concerning the public participation in environmental protection- Article 6 is about decision making in certain issues, Article 7 deals with public participation in decision-making on environmental issues, specifically on the participation in making of plans, programs and policies related to the environment and Article 8 is about participation during preparation of laws, legislations and legally binding normative instruments [43]. Awareness of environmental protection in Croatia must be converted into a clear, comprehensive and long-term concept, particularly because of the next years' accession to the European Union (EU). Strengthening the social capital, and better public education and information allows high level participation in decision making. This step, of course, should cause changes in the organizational as well as in the legislation forms. Therefore, the natural resources management requires an integrated and multidisciplinary approach. Building up social capital is one of the pre-requisites for a high-level participation in management of natural resources, which could be done by strengthening education and awareness of citizens on participation in decision making. All of this can be achieved by adequate implementation of the Aarhus Convention. Croatia has a long practice in the area of carrying out EIAs and involving the public in the process, since this is an area that has been regulated since 1984 [44]. This research showed that participation is not something new or an innovation in this part of the world, as in administrative practice in Croatia it already existed in Former Yugoslavian times (the first process in 1989). Research results have shown clear indications of discrimination against those requirements by state officials that are considered as "provocative" or made "for purely political reasons." The easiest way is not to give answer to them or just simply disqualify them as such. It should be noted that the most common requests for environmental information relating to information is about land use. The intensity of public participation depends on specific issues, and how the media informed and placed information's on the topic. In Medvednica's case that was conducted with a really strong intensity and rebel on the public forum due to the previous media articles. With that an area is left for manipulation of certain interest groups, and the changes to the final impact on the outcome of the public forum, which is how we can describe in some manners the unofficial participation. The interest for public debates usually is not great, since there aren't many written comments afterward and there is a small number of participants present at those forums. But after the 2005 public forum in Medvednica's case there were 733 complaints made and many people were present, so with that we can see that if stakeholders recognise their interest, they actually want to be involved in the process. It is believed that the cause of abstinence is former authoritarian political culture that, despite a relatively high degree of interest in politics, it is installed in the people principles that they do not have any influence on policy and decision making processes. This makes it difficult to motivate people in participating actively. Such attitude can be countered with enhancement of the information systems of publically available data and appropriate education and consultation of people through focus groups and seminars. What is necessary is a consistent and strategic approach to decision making, good legislative process when converting decisions into binding regulations and, finally, to encourage public participation in the entire process to make sure that these decisions can take a hold in everyday society. It is necessary to identify all relevant stakeholders, in each sector, at all levels and clearly distinguish their responsibilities. Whenever possible, the forums should involve all stakeholders (including citizens), NGOs and people from relevant professional background as well as the broad science community.

\section{ACKNOWLEDGMENTS}

Thanks to my both supervisors Prof. Dr. Werner Konold and Prof. Dr. Margaret A. Shannon for continuous contribution with their comments to my thesis. Thanks to CFRI and its director, PhD Dijana Vuletić for giving me a chance to continue with this research. This work was supported by the EFI FOPER project with a mobility grant. 


\section{REFERENCES}

1. PRENDERGAST J R, QUINN R M, LAWTON J H, EVERSHAM B C, GIBBONS D W 1993 Rare species, the coincidence of diversity hotspots and conservation strategies. Nature 365 (6444): 335-337

2. SCHMEER K, 1999 Guidelines for Conducting a Stakeholder Analysis. Bethesda, MD, Partnerships for Health Reform, Abt Associates Inc., p 8-10

3. BRUGHA R, VARVASOVSZKY Z 2000 Stakeholder analysis: a review. Health Policy Plann 15 (3): 239-246

4. VARVASOVSZKY Z, BRUGHA R 2000 A stakeholder analysis. Health Policy Plann 15 (3): 338-345

5. BLAIR J D, FOTTLER M D 1990 Challenges in Health Care Management: Strategic Perspectives for Managing Key Stakeholders. San Francisco, Jossey-Bass Publishers

6. GRIMBLE R, CHAN M K 1995 Stakeholder analysis for natural resource management in developing countries. Some practical guidelines for making management more participatory and effective. Nat Resour Forum 19 (3): $113-124$

7. CHEVALIER J M, BUCKLES D 1999 Conflict management: A hetero cultural perspective. In: Buckles D (ed) Cultivating Peace: Conflict and Collaboration in Natural Resource Management. International Development Research Centre, Ottawa, Canada, p 13-44

8. GRIMBLE R, WELLARD K 1997 Stakeholder methodologies in natural resource management: a review of principles, contexts, experiences and opportunities. Agr Syst 55 (2): 173-193

9. DE LOPEZ T T 2003 Economics and stakeholders of Ream National Park, Cambodia. Ecol Econ 46 (2): 269282

10. NEPAL S K, WEBER K E 1995 Prospects for coexistence: Wildlife and local people. Ambio 24 (4): 238-245

11. ROCKLOFF S F, LOCKIE S 2004 Participatory Tools for Coastal Zone Management: use of Stakeholder Analysis and Social Mapping in Australia. Journal of Coastal Conservation 10 (3-4): 81-92

12. MUSHOVE P, VOGEL C 2005 Heads or tails? Stakeholder analysis as a tool for Conservation Area management. Global Environ Chang 15 (3): 184-198

13. ELIOT L 2001 Ask these questions to reach your stakeholders Management. Global Environ Chang 15: 184188

14. SVENDSEN A C, BOUTLIER R G, ABBOT R, WHEELER D 2004 Measuring the business value of stakeholder Vancuver, BC, Simon Fraser Centre for Innovation in Management. Available at: http://www.cica.ca/ (Accessed: 20 July 2010)

15. SAVAGE G T, NIX T W, WHITEHEAD C J, BLAIR J D 1991 Strategies for assessing and managing organizational stakeholders. Acad Manage Exec 5 (2): 61-75

16. MITCHELL R K, AGLE B R, WOOD D J 1997 Toward a Theory of Stakeholder Identification and Salience: Defining the Principle of Who and What really Counts. Acad Manage Rev 22 (4): 853-888

17. CLELAND D I 1999 Project management Strategic design and implementation. 3rd edition, New York, McGraw-Hill.

18. BRIINER W, HASTINGS C, GEDDES M 1996 Project leadership. New York, Van Nostrnd Reinhold 2nd ed., Aldershot,England; Brookfield, Vt: Gower

19. FLETCHER A, GUTHRIE J, STEANE P, ROOS G, PIKE S 2003 Mapping stakeholder perceptions for a third sector organization. Journal of Intellectual Capital 4 (4): 505- 527
20. FROOMAN J 1999 Stakeholder influence strategies. Acad Manage Rev 24 (2): 191-205

21. TURNER J R, KRISTOFFER V, THURLOWAY R 2002 The Project Manager as Change Agent. London, McGrawHill Publishing Co. p 264

22. DE LOPEZ T T 2001 Policy options for Cambodia's Ream National Park: A stakeholder and economic analysis. Economy and Environment Program for Southeast Asia (EEPSEA), Singapore, p 269-282

23. CHO K J 2009 Developing an interpretative planning model for a national park system: A stakeholder-based needs assessment study for Korea. PhD dissertation, The Ohio State University, p 247.

24. PRELL C, HUBACEK K, REED M 2009 Stakeholder Analysis and Social Network Analysis in Natural Resource Management. Society and Natural Resources 22 (6): 501-518

25. SUMAN D, SHIVLANI M, ILON J W 1999 Perceptions and attitudes regarding marine reserves: a comparison of stakeholder groups in the Florida Keys National Marine Sanctuary. Ocean Coast Manage 42 (12): 1019-1040

26. JENNINGS S F, LOCKIE S 2002 Democratisation and capacity building in coastal zone decision-making in Australia: the application of stakeholder analysis and social mapping. Paper presented at the Coastal Zone Asia Pacific Conference, Bangkok, TH, 12-16 May 2002

27. CHRISTIE P 2004 Marine Protected Areas as Biological Successes and Social Failures in Southeast Asia. Am Fish S S 42:155-164

28. RENARD Y, BROWN N, GEOGHEGAN T 2001 Stakeholder approaches to natural resource management in the Caribbean. Regional Conference on Community-Based Coastal Resource Management Mérida, Mexico 19-20 Juni 2001

29. SHEPARD G, 2004 The ecosystem approach - Five steps to implementation. IUCN Publications Services Unit, Ecosystem Management Series No. 3

30. BRENNER B 2001 Stakeholder management and ecosystem management: A stakeholder analysis of the Great Smoky Mountains National Park. MBA Thesis, Vienna University of Economics and Business Administration, $\mathrm{p} 153$

31. ENSERINK E 2000 A quick scan for infrastructure planning: screening alternatives through interactive stakeholder analysis. Impact Assessment and Project Appraisal 18 (1): 15-22

32. PARLIAMENT OF SOCIALISTIC REPUBLIC OF CROATIA 1981 Act to designate the western part of Medvednica Nature Park. Official Gazette, Zagreb, 24

33. CROATIAN PARLIAMENT 2005 Law on nature protection. Official Gazette, Zagreb, 07

34. MINISTRY OF CONSTRUCTION AND PHYSICAL PLANNING 1997 Spatial Planning Strategy of Croatia. Naklada Zadro, Zagreb, p 168

35. CROATIAN PARLIAMENT 2007 Law on spatial planning and Construction. Official Gazette, Zagreb, 76

36. ARNSTEIN S R 1969 A Ladder of Citizen Participation: J Am I Planners 35 (4): 216-224

37. IFC 1998 Doing Better Business Through Effective Consultation and Disclosure. Available at: http:// www.ifc.org/ifcext/enviro.nsf/AttachmentsByTitle/p pubconsult/\$FILE/PublicConsultation.pdf (Accesed :15 July 2010)

38. BROWN J T 2007 The handbook of program management. McGraw-Hill, p 288 
39. INTERNATIONAL ASSOCIATION OF PUBLIC PARTICIPATION, IAP2 2004 Public participation spectrum. Available at: http://www.iap2.org.au/sitebuilder/resources/ knowledge/asset/files/36/iap2spectrum.pdf (Accesed: 20 October 2011)

40. INTERNATIONAL INSTITUTE FOR ENVIRONMENT AND DEVELOPMENT, Power Tools: for policy influence in natural resource management (iied). Available at: http:// www.iied.org/natural-resources/key-issues/empowerment-and-land-rights/power-tools-for-policy-influencenatural-re (Accesed: 10 June 2011)

41. CROATIAN PARLIAMENT 2009 Law Amendments to the Act to designate the western part of the Nature Park Medvednica. Official Gazette, Zagreb, 25
42. EUROPEAN PARLIAMENT 2006 Regulation on the application of the provisions of the Aarhus Convention on Access to Information, Public Participation in Decisionmaking and Access to Justice in Environmental Matters to Community institutions and bodies. Regulation no. 1367/2006. http://eurlex.europa.eu/LexUriServ/LexUriServ.do?uri=OJ:L:2006:264:0013:0019:EN:PDF (Accesed: 5 February 2012)

43. OFAK L 2009 Sudjelovanje javnosti u odlučivanju u pitanjima okoliša (Public Participation in environmental issues decision making). Hrvatska javna uprava: opis za teoriju i praksu javne uprave, 9 (2): 443-470

44. BAN A 2004 Croatian Accession to the European Union: Institutional Challenges. Institute of Public Finance 2: 223-248 
